
\title{
cemoti $\begin{aligned} & \text { Cahiers d'études sur la Méditerranée } \\ & \text { orientale et le monde turco-iranien }\end{aligned}$
}

18 | 1994

Le Tadjikistan existe-t-il ? Destins politiques d'une « nation imparfaite "

\section{Réflexion sur quelques effets du passage de génération dans l'intelligentsia contemporaine du Tadjikistan, trad. du russe par Stéphane A. Dudoignon}

Parviz MULLADJANOV

\section{(2) OpenEdition \\ Journals}

Édition électronique

URL : http://journals.openedition.org/cemoti/239

DOI : $10.4000 /$ cemoti.239

ISSN : $1777-5396$

Éditeur

AFEMOTI

Édition imprimée

Date de publication : 1 juillet 1994

Pagination :

27-36

ISSN : 0764-9878

Référence électronique

Parviz MULLADJANOV, « Réflexion sur quelques effets du passage de génération dans l'intelligentsia contemporaine du Tadjikistan, trad. du russe par Stéphane A. Dudoignon », Cahiers d'études sur la Méditerranée orientale et le monde turco-iranien [En ligne], 18| 1994, mis en ligne le 30 mars 2004, consulté le 08 septembre 2020. URL : http://journals.openedition.org/cemoti/239 ; DOI : https:// doi.org/10.4000/cemoti.239

Ce document a été généré automatiquement le 8 septembre 2020.

Tous droits réservés 


\title{
Réflexion sur quelques effets du passage de génération dans l'intelligentsia contemporaine du Tadjikistan, trad. du russe par Stéphane A. Dudoignon
}

\author{
Parviz MULLADJANOV
}

\section{RÉSUMÉS}

Les clivages démographiques mis au jour par Valentin Bushkov sont aussi à l'origine de la fracture qui a partagé l'intelligentsia nationale du Tadjikistan en deux tendances hostiles. Les premières générations de lettrés de l'appareil, recrutés depuis la fin des années 1920 dans l'élite urbaine persanophone de Samarcande, de Boukhara et des cités du Ferghana (y compris Khoudjand) ont dû faire face pendant la décennie précédant le conflit armé à la montée en puissance d'une jeune intelligentsia issue des communautés montagnardes du Tadjikistan central, installées dans les vallées cotonnières depuis les années 1950. L'affrontement entre ces deux " générations » a eu pour résultat la dislocation de l'intelligentsia de type européen formée à Douchanbeh par le régime soviétique. Fragilisée puis marginalisée par d'autres acteurs, l'intelligentsia s'est trouvée exclue du champ politique, tandis que Douchanbeh subissait un phénomène de déseuropéanisation, accru par le départ en masse des russophones. 